\title{
Low Economic Benefits of Fish as Source of Fish Albumin Besides Cork Fish
}

\author{
Nur Fatma \\ Ph.D candidate in Fishery Science, \\ Faculty of Marine and Fishery \\ Sciences, Hasanuddin University \\ Makassar \\ nurfatma104@gmail.com
}

Mala Nurilmala

Department of Aquatic Food Product

Technology, Faculty of Fishery and

Marine Sciences, Bogor Agricultural

University

Bogor

mnurilmala@ipb.ac.id

\author{
Metusalach * \\ Department of Fishery, Faculty of \\ Marine and Fishery Sciences, \\ Hasanuddin University \\ Makassar \\ mminanga@hotmail.com
}

Nurfaidah

Ph.D candidate in Fishery Science,

Faculty of Marine and Fishery

Sciences, Hasanuddin University

Makassar

nurfaidahanwah@gmail.com

\author{
Nurpudji Astuti \\ Department of Clinical Nutrition, \\ Faculty of Medicine, Hasanuddin \\ University \\ Makassar \\ pudji_taslim@yahoo.com
}

\begin{abstract}
The high intensity of use of cork fish (snakehead fish) to produce various products of fish albumin has put the natural stock of this fish species under a great pressure. Therefore, it is necessary to find alternative sources of fish albumin other than the cork fish. The purpose of this study was to analyze the albumin contents in two species of marine fish of low economic value. The fish used were red fusilier (Caesio chrysosonus) and Japanese threadfin bream (Nemipterus japonicus). The soluble protein and albumin were extracted by homogenizing100 $\mathrm{g}$ of fish meat in distilled water $(1: 4 \mathrm{w} / \mathrm{v})$. The mixture was heated in a shaking water bath at $50^{\circ} \mathrm{C}$ for $1 \mathrm{~h}$ and then filtered with a Whatman no. 40 filter paper. The total protein content of meat and filtrate was analyzed following the Kjeldahl method while the albumin content in the filtrate was measured according to the Lowry method. The results showed that the total protein content of C. chrysosonus and $\mathrm{N}$. japonicus was $22.13 \%$ and $22.27 \%$, respectively, whereas that of the filtrate was $25.77 \%$ and $28.36 \%$, respectively. The albumin content in the $C$. chrysosonus was very low $(1.08 \%$ of meat, w/w) while $\mathrm{N}$. japonicas contained a moderate level of albumin $(2.32 \%$ of meat, w/w). The Japanese threadfin bream is a potential source of fish albumin.
\end{abstract}

Keywords: fish albumin, marine fish, Japanese bream, protein, red fusilier

\section{INTRODUCTION}

Albumin is the main constituent of protein in plasma constituting an approximately $60 \%$ of the total plasma protein which is equal to about $4.5 \mathrm{~g} / \mathrm{dl}$ [1]. Albumin has a crucial role in maintaining blood osmotic pressure, helps in transporting metabolites (fatty acids, hormones, billirubin) and filtering fluids in body tissues $[2,3,4,5,6]$. Albumin is a type of globular proteins that is easily soluble in water and in dilute saline solvents and is coagulated by heat [7].

Albumin is traditionally obtained from egg white, human serum albumin (HSA) and bovine serum albumin (BSA). Recently, fish albumin particularly that of cork fish (snakehead fish) albumin has been used as an alternative source of albumin to substitute the very expensive HAS.
Cork fish albumin has been reported to be efficacious to increase albumin levels in the body of hypoalbumin patients. The intake of cork fish by postoperative patient with a low albumin levels increases the albumin in the body to a normal level [8]. Also, the administration of cork fish albumin capsules to stroke patients can improve nutritional status and immunity [9].The benefit of consuming snakehead fish has long been realized by ancestors of Asian communities. In the past, the juice of steamed snakehead fish was given to post-delivering women since it was believed to be capable of accelerating the wound healing process and recovery [10]. The snakehead fish extract was also used to treat wounds due to its role in plastic process of new cell tissue in the body [11].

The increase use of the cork fish albumin has resulted in high demand and put the natural stock of this species under high pressure, thus inducing fears on the sustainability of natural stock of the species. Therefore, an alternative source of albumin is needed either as a supplement or a substitute to the cork fish albumin. This study was aimed at analyzing the protein and albumin contents of two low economic values of marine fish to determine their potential as an alternative source of fish albumin to the cork fish.

\section{MATERIALS AND METHODS}

The type of fish used in this study was chosen based on their high abundance and low economic value. The fish studied consisted of two marine fish species, red fusilier (Caesio chrysosonus) and Japanese threadfin bream (Nemipterus japonicus) (Fig. 1 and 2). Chemical used during the study including bovine serum albumin (BSA) as a standard albumin, distilled water, $\mathrm{H}_{2} \mathrm{SO}_{4}, \mathrm{NaOH}, \mathrm{HCl}$, $\mathrm{H}_{3} \mathrm{BO}_{3}$, methyl red indicator, $\mathrm{NaHCO}_{3}, \mathrm{Na}-\mathrm{K}$ tartaric $1 \%$, $\mathrm{CuSO}_{4}$, phenol reagent. The fish samples were randomly collected from newly landed fish. The selected fish samples were immediately transported to the laboratory in a cool-box with slurry ice to maintain freshness. Sample preparation was carried out by removing 
gills and internal organs, thoroughly washed under running water and allowed to drip. Then, the fish was filleted and the meat was separated from bones and skin. The meat was then finely chopped, pre-homogenized with a commercial blender, packed in a zipped high density polyethylene plastic bag and frozen storage until used for analysis.

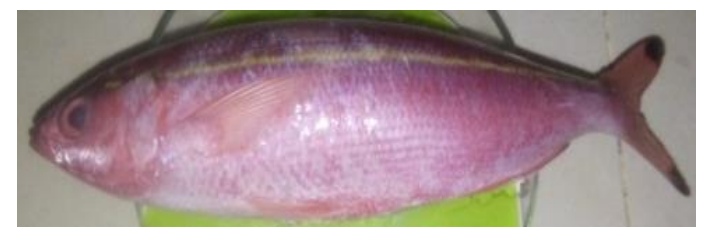

Fig. 1. Red fusilier (C. chrysosonus)

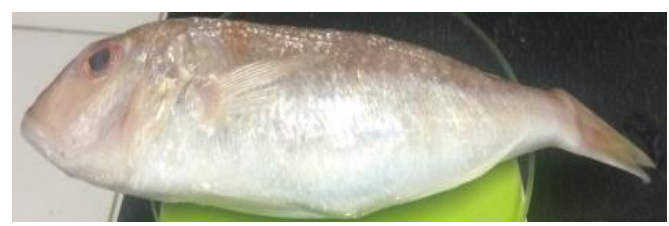

Fig. 2. Japanese threadfin bream (N. japonicas)

Soluble protein and albumin were extracted from $100 \mathrm{~g}$ of pre-homogenized fish meat with four volume of distilled water $(1: 4, w / v)$. The mixture was homogenized for about one minute in a laboratory waring blender. The homogenized sample was then heated in a shaking water bath at $50^{\circ} \mathrm{C}$ for one hour. After heating, the sample was filtered through a Whatman no. 40 filter paper under reduced pressure. The filtrate was the transferred to a capped glass bottle and stored in a fridge until analyzed.

The analysis was performed for the total protein in fish meat, total soluble protein, and albumin content in the extract. The content of protein in meat and in extract was determined using the Kjeldahl method, whereas the content of albumin in extract was analyzed following the Lowry method. The albumin content was measured using a UVVis spectrophotometer at a wave length of $650 \mathrm{~nm}$. A standard curve was prepared by measuring the absorbance of BSA at a concentration of $0,0.2,0.4,0.6,0.8$ and 1.0 $\mathrm{mg} / \mathrm{ml}$ at $650 \mathrm{~nm}$ wave length.

\section{RESULTS}

The red fusilier and the Japanese threadfin bream showed a similar total protein content in their meat at 22.13 and $22.17 \%$, respectively (Fig. 3). These total protein content indicated that the fish studied can be classified as fish having very high protein levels. Both fish species are members of demersal fish dwelling in muddy, sandy and reef habitats.

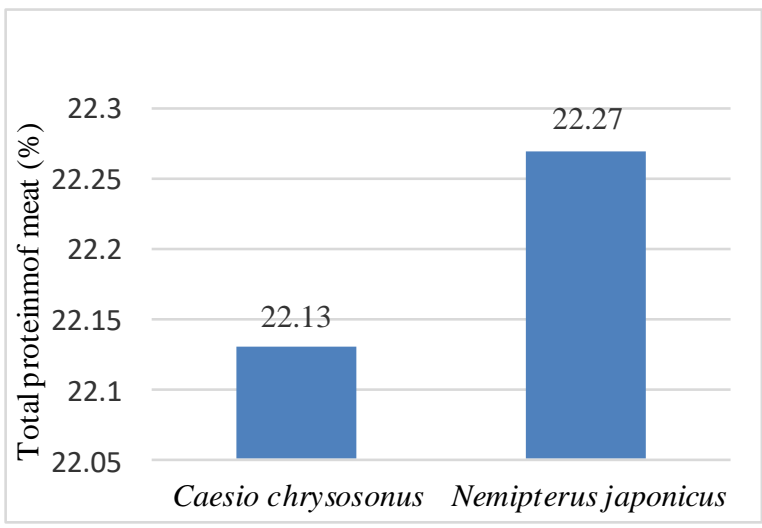

Fig. 3. Total protein content of the fish meat $(\%, w / w)$

The total soluble protein content of the red fusilier fish extract was $25.77 \%$ of the meat protein corresponding to $5.70 \%$ of the meat weight, whereas the protein content of the extract of the Japanese threadfin bream was $28.36 \%$ of the meat protein or $6.32 \%$ of the meat weight (Fig. 4). The soluble protein is usually made up by low molecular weights of proteins and non-protein nitrogen compounds such as amino acids, nucleotides, trimethylamine and its oxide form, dimethylamine, urea, and other nitrogencontaining substances.

The protein content of the red fusilier fish extract was $25.77 \%$ of the meat protein corresponding to $5.70 \%$ of the meat weight, whereas the protein content of the extract of the Japanese threadfin bream was $28.36 \%$ of the meat protein or $6.32 \%$ of the meat weight (Fig. 4).

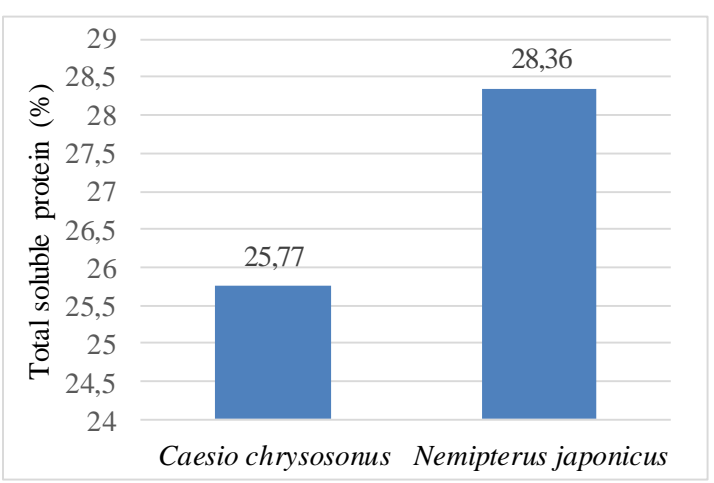

Fig. 4. Total soluble protein content (\% of meat protein) in the fish extract

The albumin level the red fusilier and the Japanese threadfin bream is shown in Fig. 5. Low level of albumin was found in the red fusilier $(4.88 \%$ of the meat protein corresponding to $1.08 \%$ of the meat weight). The albumin level in fish is affected by intrinsic factors including species, size of fish, level of maturity, and sex, as well as extrinsic factors such as season, food availability, habitat, method and condition of extraction. 


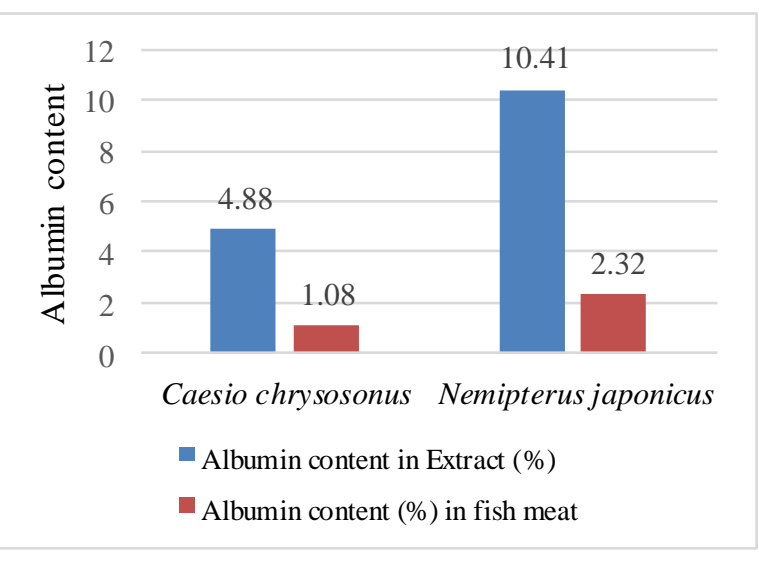

Fig. 5. The albumin content of the red fusilier and Japanese threadfin bream fish

The fish used in this study contained different level of total protein and albumin of the extracts. The solubility of different proteins is influenced by $\mathrm{pH}$, ionic strength, molecular size, and conjugation with other molecules. As for albumin, since it is easily coagulated by high heat, the extraction has to be done at lower temperature to avoid low recovery level. The significant effect of different temperature on albumin level has been reported in a previous study [12]. Albumin coagulation temperature is between $56-72^{\circ} \mathrm{C}$, depending on composition of its amino acids, the presence of disulfide bonds, salt bridges, heating time and water content $[13,14]$.

\section{DISCUSSION}

The protein content of fish varies among species and is influenced by internal and external factors, such as food habits, sex, size, age, season, environmental conditions, geographical location and food abundance $[15,16,17,18]$. The protein contents of fish in this study were higher than those of fish previously reported [19]. These authors found that the protein content of gray mullet (Liza tade) was $18.90 \%$, catfish (C. batrachus) was $18.43 \%$, barramundi (L. calcarifer) $17.11 \%$, climbing perch (Anabas testudineus) was $18.92 \%$. Another species of Japanese threadfin bream (N. nematophorus) was reported to have protein content of $16.85 \%$ [20]. The protein contents in fish ranged from 16 to $22 \%$ of the total muscle mass [21]. Protein is the second highest compound in fish after water. Protein plays a vital role in the structure and function of the body, such as growth and reproduction [22].

The proportion of the soluble protein is higher in the Japanese threadfin bream as compared to that of the red fusilier. Both fish used in this study showed higher soluble protein levels than that of the Pangas catfish (Pangasius pangasius) which was between $1.7-3.4 \%$ and of the snakehead fish $(3.34 \%)$ [23,24]. The soluble protein is known as sarcoplasmic protein consisted of low molecular weight fraction of proteins.

The albumin content ( $\%$ of the meat weight) of the red fusilier was comparable to that of C. striata $(1.39 \%)$ and barramundi (0.57\%) [19], and C. striata from West Java
(1.07\%) [25], as well as of C. striata from Central and East Java $(0.76 \%$ and $0.91 \%$, respectively) [26]. A much higher level of albumin was shown by the Japanese threadfin bream $(10.41 \%$ of the meat protein or $2.32 \%$ of the meat weight. Variation in the albumin content depends on fish species, size, diet consumption rate, dietary availability and digestibility rate [27].

\section{ACKNOWLEDGMENT}

We are grateful to the Directorate of Research and Community Service of the Directorate General of Research and Technology Strengthening Development of the Ministry of Research, Technology, and Higher Education, Republic of Indonesia for funding this research.

\section{REFERENCES}

[1] R.K. Murray, D.K. Granner, P.A. Mayer, and V.W. Rodwell, Harper's Biochemistry, Canada: Appletonang Lange, 1993

[2] H. D. Smet, R. Blust, and L. Moens, "Absence of albumin in the plasma of the common carp Cyprinus carpio: binding of fatty acids to high density lipoprotein," Fish Physiol. Biochem., vol. 19, pp. 7181, 1998

[3] A.D. Sediaoetama, Nutrition Science for Students and Profession, vol. 1, Jakarta: Dian Rakyat, 2000

[4] M.E. Baker, "Albumin, steroid hormones and the origin of vertebrates," J. Endocrinol, vol. 175, pp. 121-127, 2002

[5] A.M. Andreeva, "Mechanisms of the plurality of Scorpaena porcus L. serum albumin," Open J.Mar. Sci., vol. 1, pp. 31-35, 2011

[6] T.B. Kovyrshina and I. I. Rudneva, "Comparative study of serum albumin level in round goby Neogobius melanostomus form Black Sea and Azov Sea," Int. J. Adv. Biol. Res., vol. 2, pp. 203-208, 2012

[7] M.A. Masuelli, "Study of bovine serum albumin solubility in aqueous solutions by intrinsic viscosity measurements," Adv. Phys. Chem., vol. 2013, Article ID 360239, 8 p. 2013.

[8] I.S. Wahyuni, Y. Peristiowati, S. Siyoto, The effect of curing fish (albumin) on the increase in albumin levels in postoperative patients with hypoalbumin in the hospital of dr. Iskak Tulungagung. 2013.

[9] V.N. Kasim, S.M. Pateda, V. Hadju, and N. Jafar, "Supplementation of cork fish albumin extract on nutritional status and immunity of stroke patients," Indonesian Clinical Nutrition Journal, vol. 13, no. 3, pp. 91-98, January 2017

[10] M.M.A Shafri and A.M.J. Manan, "Therapeutic potential of the Haruan (Channastriatus): from food to medicinal uses. Malays," J. Nutr., vol. 18, pp. 125-136, 2012

[11] A.A.B. Putri, Yuliet, and Jamaluddin, "Analisis kadar albumin ikan sidat (Anguilla marmorata dan Anguilla bicolor) dan uji aktivitas penyembuhan luka terbuka pada kelinci (Oryctolagus cuniculus)," GALENIKA J. Pharm., vol. 2, no. 2, pp. 90-95, 2016

[12] S.T. Dwi, S.T.M. Sulthoniyah, and E. Suprayitno, "The effect of steaming temperature on the nutritional and organoleptic content of cork shredded fish (Ophiocephalus striatus)," Brawijaya University THPI Student Journal, vol. 1, no. 1, pp 33-45, 2012

[13] I. Chayati and A.A. Andian, Diktat Food Chemistry, Yogyakarta: Yogyakarta State University, 2008

[14] J.M. De Man, Food Chemistry, Translated by P. Kosasih, Bandung: Institut Teknologi Bandung, 1997

[15] H.E. Irianto and I. Susilo, Dukungan teknologi penyediaan produk pangan: Dipaparkan dalam Seminar Nasional Hari Pangan Sedunia

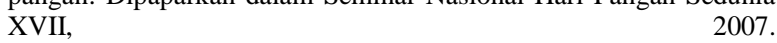
http://www.litbang.pertanian.go.id/special/HPS/dukungan_tek_perik anan.pdf.

[16] S. Mol, T. Baygar, C. Varlik, and S.Y. Tosun, "Seasonal variations in yield, fatty acids, amino acids and proximate compositions of sea urchin (Paracentrotus lividus) roe," J. Food and Drug Anal., vol. 16, no. 2, pp.68-74, 2008

[17] D. Ayas and Y. Ozogul, "The chemical composition of carapace meat of sexually mature blue crab (Callinectes sapidus, Rathbun 
1896) in the Mersin Bay,” J. Fish. Sci., vol. 38, pp. 645-650, 2011. https://doi.org/10.3153/jfscom.2011030

[18] O.O. Fawole, T.A. Yekeen, S.O. Adewoye, M.A. Ogundiran, O.E. Ajayi, and M.N. Nwaiya, "Nutritional qualities and trace metals concentration of six fish species from Oba reservoir, Ogbomoso, Nigeria," African J. Food Sci., vol. 7, no. 8, pp. 246-252, 2013. https://doi.org/10.5897/AJFS2013.0994.

[19] R. Susilowati, Sugiyono, and E. Chasanah, "Nutritional and albumin content of swamp fishes from Merauke, Papua, Indonesia. Squalen Bull. Mar. and Fish," Postharvest and Biotechnol, vol. 11, no. 3, pp. 107-116, 2016

[20] B.B. Sedayu, "Effect of frozen storage time of crated fish meat (Nemipterus nemathophorus) on surimi's physical-chemical quality [Thesis]," Aquatic Product Technology Study Program, Faculty of Fisheries and Marine Sciences, Bogor Agricultural University, Bogor, 2004

[21] H.H. Huss, "Quality and quality changes in fresh fish," FAO Fisheries Technical Paper 34, 1995

[22] Ramlah, E. Soekendarsi, Z. Hasyim and M.S. Hasan," Comparison of the nutrient content of Oreochromis niloticus tilapia from Lake Mawang, Gowa Regency, and Lake Hasanuddin University, Makassar City," Makassar Biology Journal (Bioma), vol. 1, no. 1, pp. 39-46, 2016

[23] N. Rahmawati, "Kandungan protein terlarut daging ikan patin (Pangasius pangasius) akibat variasi pakan tambahan [Skripsi]," Fakultas Matematika dan Ilmu Pengetahuan Alam. Universitas Jember, 2014

[24] A. Mustafa, M.A. Widodo, and Y. Kristianto, "Albumin and zinc content of snakehead fish (Channa striata) extract and its role in health,” Int. J. Sci. Technol., vol. 1, no. 2, pp. 1-8, 2012.

[25] R. Susilowati, H.I. Januar, D. Fithriani, and E. Chasanah, "Potensi ikan air tawar budidaya sebagai bahan baku produk nutraseutikal berbasis serum albumin ikan," J. Pascapanen dan Biotek. Kelautan dan Perik, vol. 10, no. 1, pp. 37-44, 2015. DOI: http:// dx.doi.org/10.15578/jpbkp.v10i1.243

[26] E. Chasanah, M. Nurilmala, A.R.Purnamasari, and D.Fithriani, "Komposisi kimia, kadar albumin dan bioaktivitas ekstrak protein ikan gabus (Channa striata) alam dan hasil budidaya," J. Pascapanen dan Biotek. Kelautan dan Perik, vol. 10, no. 2, hal. 123 132, 2015

[27] Y. Niwa, M.H. Irma, H. Rinaand, and W. Yoyo, Nutrisi dan bahan pakan ikan budidaya, Jambi: Balai Budidaya Air Tawar, 2007. 